\title{
WYNIKI SPORTOWE A DOCHODOWOŚĆ AKCJI SPÓŁEK-SPONSORÓW NA PRZYKŁADZIE PIŁKI SIATKOWEJ
}

\section{Marek Szymański*, Grzegorz Wojtalik**}

\section{SPORTS RESULTS AND THE PROFITABILITY OF SPONSORSHIP COMPANIES ON THE EXAMPLE OF VOLLEYBALL CLUBS}

\begin{abstract}
The purpose of the article is to investigate the relationship between the sports performance of volleyball teams in Poland and the rates of return of the titular sponsors, whose shares are listed on the Warsaw Stock Exchange. The four most successful Polish PlusLiga volleyball teams in the 21st century were selected for this study.

Methodology: The article describes the results carried out using ARCH and GARCH models.

Results of the research: Two groups of results were obtained. For two companies - JSW and ASSECO - the sports results of volleyball teams and betting forecasts for their matches had a statistically significant impact on the stock performance of these companies. For two companies - PGE and Azoty - no such relationship has been found. Moreover, all of the stock returns were significantly influenced by the WIG index. On the other hand, neither of the companies were influenced by the match day.
\end{abstract}

Keywords: economics of sport, stock exchange, ARCH and GARCH models, sport results, volleyball. JEL Class: C58, D53, Z23.

\footnotetext{
* Mgr, Wydział Ekonomiczno-Socjologiczny, Uniwersytet Łódzki; https://orcid.org/0000-0001-5762-4840.

${ }^{* *}$ Mgr, Wydział Ekonomiczno-Socjologiczny, Uniwersytet Łódzki; https://orcid.org/0000-0003-0744-4328.
} 


\section{WSTĘP}

Współczesny sport komercyjny jest ściśle związany z pieniędzmi. Sport zawodowy nie mógłby funkcjonować bez pieniędzy sponsorów, dlatego wiele klubów sportowych stara się zadbać o jak najbardziej korzystne warunki dla potencjalnych sponsorów.

Obecnie sponsoring drużyn siatkarskich w Polsce stał się bardzo atrakcyjny dla przedsiębiorstw. Sukcesy polskich drużyn klubowych oraz reprezentacyjnych przyciągnęły rzeszę kibiców. Wartość medialna profesjonalnych lig siatkówki w Polsce wyceniana była na 582 miliony złotych w 2017 roku (Strategia rozwoju Polskiej...). Biorąc pod uwagę fakt, że siatkówka jest jedną z najpopularniejszych dyscyplin sportowych w Polsce, naturalne jest poszukiwanie powiązań między sportem a rynkami finansowymi.

Wszystkie badania wpływu wyników sportowych na kursy akcji do tej pory koncentrowały się w obszarze piłki nożnej, natomiast nie został zbadany wpływ w innych dyscyplinach sportowych. Piłka nożna pozostaje jednym z najpopularniejszych sportów, szczególnie w Europie, jednak Autorzy uważają, że wartym uwagi jest również zbadanie wpływu rezultatów sportowych w innych sportach drużynowych. Celem pacy jest zbadanie zależności między wynikami sportowymi drużyn siatkarskich mężczyzn w Polsce a dochodowością akcji sponsora tytularnego, którego akcje notowane są na Giełdzie Papierów Wartościowych w Warszawie. Przez dochodowość akcji należy rozumieć stopę zwrotu z akcji danej spółki. Autorzy przypuszczają, że wygrane i przegrane drużyn sponsorowanych mogą wywierać istotny statystycznie wpływ na ceny akcji. Do badania wybrano 4 najbardziej utytułowane drużyny siatkarskiej PlusLigi w XXI wieku. Do oszacowania zależności użyto modeli ARCH i GARCH. Tematami łączącymi sport i rynek kapitałowy w Polsce zajmował się m.in. Sebastian Majewski. Wcześniejsze badania dotyczyły głównie piłki nożnej jako najbardziej popularnego sportu na świecie. W pracy zostaje podjęta próba wyjaśnienia wpływu innego sportu popularnego w Polsce - jakim jest siatkówka. Jest to nowatorskie podejście do tematu zarówno w Polsce jak i na świecie.

W wewnętrznej konstrukcji pracy wyróżniono sześć części. W pierwszej części omówiona zostanie historia siatkówki oraz klubów siatkarskich w Polsce. W drugiej szczegółowo zostanie przedstawiony sponsoring w sporcie oraz jego wpływ na polski rynek siatkarski. W części trzeciej przedstawiono przegląd literaturowy. Czwarta część przedstawia metodykę badania. W kolejnej części określono próbę badawczą na której przeprowadzono badania. W ostatniej części przedstawione zostaną wyniki oraz wnioski płynące ze zbadanych zależności między wynikami sportowymi, a dochodowością akcji spółek - sponsorów tytularnych - notowanych na Giełdzie Papierów Wartościowych w Warszawie. 


\section{HISTORIA SIATKÓWKI ORAZ KLUBÓW W POLSCE}

Początek zorganizowanej siatkówki w Polsce datuje się na 1928 r. Pierwsze Mistrzostwa Polski odbyły się rok później w Warszawie, gdzie triumfowali siatkarze YMCA Łódź oraz siatkarki AZS Warszawa. Reprezentacja Polski swój pierwszy oficjalny mecz rozegrała w 1948 r. przeciwko Czechosłowacji, a debiut naszej kadry narodowej na mistrzostwach świata nastąpił w 1949 r. Od 1954 r. w Polsce organizowane są rozgrywki ligowe.

30 czerwca 2000 roku podczas posiedzenia Polskiego Związku Piłki Siatkowej w Poznaniu założono Profesjonalną Ligę Piłki Siatkowej SA (PLPS SA). Tego dnia, przed meczem Polska-Hiszpania w Lidze Światowej, uroczyście podpisano jej akt notarialny. Podmiot ten odpowiedzialny był za zorganizowanie i docelowe prowadzenie profesjonalnych rozgrywek męskiej ligi zawodowej, której nadano nazwę Polska Liga Siatkówki.

W 2008 roku Polska Liga Siatkówki zmieniła oficjalną nazwę na PlusLigę. Liga ta, to najwyższa w hierarchii klasa męskich ligowych rozgrywek siatkarskich w Polsce, będąca jednocześnie najwyższym szczeblem centralnym. Zmagania w jej ramach toczą się cyklicznie systemem kołowym $\mathrm{z}$ fazą play-off na zakończenie każdego z sezonów i przeznaczone są dla najlepszych polskich klubów piłki siatkowej, a triumfator zostaje Mistrzem Polski. Czołowe zespoły klasyfikacji końcowej każdego sezonu uzyskują prawo występów w europejskich pucharach w sezonie następnym. Organizatorem i organem prowadzącym rozgrywki jest Polska Liga Siatkówki SA (PLS SA).

Obecnie w PlusLidze w każdym sezonie rywalizuje ze sobą 14 drużyn. W badaniu wykorzystano wyniki drużyn, które w ciągu ostatnich 10 lat osiągały największe sukcesy w Polsce, ale również na arenie międzynarodowej. Dodatkowym motywem wyboru była łatwość określenia sponsora tytularnego (nazwa sponsora znajduje się w nazwie klubu) oraz obecność spółki-sponsora na giełdzie. Tymi drużynami są PGE Skra Bełchatów, Grupa Azoty Zaksa Kędzierzyn-Koźle, Jastrzębski Węgiel oraz Asseco Resovia. Poniżej zawarto krótką historię każdego z klubów oraz największe sukcesy.

KPS Skra Bełchatów SA to polski, męski klub siatkarski z siedzibą w Bełchatowie. Założony w 1930 r., sekcję siatkówki posiada od 1957 roku. W 1991 patronat nad drużyną objęła Elektrownia Bełchatów. Od 20 grudnia 2004 działa jako spółka akcyjna. Właścicielem jest stowarzyszenie EKS Skra Bełchatów które posiada $100 \%$ akcji. Dziewięciokrotny mistrz Polski (rekord ligi) i siedmiokrotny zdobywca Pucharu Polski. Od 2007 roku, występuje jako PGE Skra Bełchatów, od nazwy głównego sponsora: PGE (Polska Grupa Energetyczna). Od 2012, jako pierwsza drużyna siatkarska na świecie, a zarazem pierwsza (i jedyna) polska drużyna sportowa, współpracuje z UNICEF. 
Chronologia nazw drużyny:

- 1957: Robotniczy Klub Sportowy (RKS) Skra Bełchatów

- 1991: Energetyczny Klub Sportowy (EKS) - Skra Bełchatów

- 2004: Klub Piłki Siatkowej (KPS) Skra Bełchatów

- 2006: BOT Skra Bełchatów

- 2007: PGE Skra Bełchatów

Skra Bełchatów to jeden z najbardziej znanych i utytułowanych klubów Polski na arenie międzynarodowej. W rozgrywkach międzynarodowych zdobywali raz srebrne oraz dwa razy brązowe medale Ligi Mistrzów Siatkarzy (odpowiednik Piłkarskiej Ligi Mistrzów). W Klubowych Mistrzostwach Świata organizowane przez Międzynarodową Federację Piłki Siatkowej dwukrotnie zdobyli srebrne medale oraz raz brązowe. Jest najbardziej utytułowanym polskim zespołem w XXI wieku.

Kolejny klub - ZAKSA SA - to polski, męski klub siatkarski z siedzibą w Kędzierzynie-Koźlu. Jeden z najbardziej zasłużonych klubów w historii polskiej siatkówki. Początki siatkówki na ziemi kędzierzyńskiej sięgają 1947 roku. W tym właśnie czasie powstał klub sportowy KS „Bierawianka”, który w 1951 roku zmienił nazwę na KS Unia Kędzierzyn. W 1994 roku rozpoczęła nowa era klubu, gdzie na bazie sekcji siatkówki Chemika Kędzierzyn - Koźle utworzona niezależny profesjonalny klub o nazwie: KS Mostostal Zabrze w Kędzierzynie Koźlu. Ośmiokrotny mistrz Polski, siedmiokrotny zdobywca Pucharu Polski, zdobywca Superpucharu Polski i medalista Ligi Mistrzów (trzecie miejsce). Od 16 lutego 2004 klub działa jako spółka akcyjna. Od sezonu 2007/2008 drużyna występuje w rozgrywkach pod nazwą ZAKSA Kędzierzyn-Koźle. W sezonie 2019/2020 drużyna występowała w rozgrywkach krajowych pod nazwą Grupa Azoty ZAKSA Kędzierzyn-Koźle.

Chronologia nazw:

- 1994: KS Mostostal Zabrze w Kędzierzynie-Koźlu (utworzony na bazie zawodników rozwiązanej sekcji siatkówki KS Chemik)

- 1995: KS Mostostal ZA Kędzierzyn-Koźle

- 1998: Mostostal Azoty Kędzierzyn-Koźle

- 2005: Mostostal-Azoty SSA Kędzierzyn-Koźle

- 2007: ZAKSA Kędzierzyn-Koźle

- 2019: Grupa Azoty ZAKSA Kędzierzyn-Koźle

Następnym utytułowanym klubem jest Jastrzębski Węgiel. Zespół ten to polski męski klub siatkarski (jednosekcyjny) z siedzibą w Jastrzębiu-Zdroju. Od 2004 roku klub funkcjonuje pod obecną nazwą. Dotychczas klub wywalczył łącznie 10 medali mistrzostw Polski: 1 złoty, 3 srebrne i 6 brązowych, a w tabeli wszech czasów MP zajmuje obecnie 15 miejsce. Drużyna Jastrzębskiego Węgla zdobyła również 5 medali Pucharu Polski: 1 złoty i 4 srebrne. W 2014 roku stanęli na najniższym stopniu podium w rozgrywkach Ligi Mistrzów. W 2011 
zdobyli drugie miejsce na Klubowych Mistrzostwach Świata. W polskiej ekstraklasie występuje nieprzerwanie od sezonu 1997/1998.

Chronologia nazw:

- 1949: LZS Jastrzębie

- 1962: Jas-Mos GKS Jastrzębie

- 1977: GKS Jastrzębie

- 1990: KS Jastrzębie Borynia

- 2001: Ivett Jastrzębie Borynia

- 2004: Jastrzębski Węgiel

Ostatnim omawianym klubem jest Asseco Resovia SA z siedzibą w Rzeszowie. Siedmiokrotny mistrz Polski, trzykrotny zdobywca Pucharu Polski oraz zdobywca Superpucharu Polski. W Lidze Mistrzów siatkarzy dwukrotnie wywalczyli drugie miejsca. Od 17 listopada 2004 klub działa jako spółka akcyjna utworzona przez AKS Resovia. Spółka zajmuje się zawodową sekcją siatkówki mężczyzn. Sponsorem tytularnym klubu jest Asseco Poland SA. Od sezonu 2006/2007 drużyna występuje w rozgrywkach pod nazwą Asseco Resovia, gdzie człon „Resovia” odnosi się do łacińskiej nazwy „Rzeszów”.

\section{SPONSORIGN W SPORCIE}

W dzisiejszych czasach pozyskiwanie klientów staje się coraz trudniejsze ze względu na rozpowszechnianie różnych rodzajów informacji i reklam. W takiej sytuacji firmy starają się znaleźć alternatywy i bardziej przyjazne sposoby komunikowania się z klientami. Jednym ze sposobów jest sponsorowanie drużyn sportowych. Sponsoring to forma promocji, którego istotą są skojarzenia, dzięki którym pozytywny obraz sponsorowanego przenosi się na sponsora. Znak sponsora najczęściej towarzyszy imprezom lub działaniu sponsorowanych instytucji. Reklamy firm, które wyświetlanie są podczas wydarzeń sportowych są lepiej akceptowalne przez kibiców, które mają je oglądać.

Sponsoring sportowy określa się jako działanie obejmujące wspieranie finansowe, za pośrednictwem usług lub środków rzeczowych (najczęściej jest to sprzęt sportowy, stroje, specjalne napoje energetyczne) sportowców, organizacji sportowych bądź imprez - w zamian za świadczenia podmiotów sponsorowanych, realizujące cele promocyjne i komunikacyjne sponsora (Iwan, 2010: 353-367).

Sponsorowanie sportu jest uważane przez przedsiębiorstwa za najbardziej efektywne z kilku powodów (Datko, 2003: 97-99):

- sport wyzwala emocje niezależnie od aktywnego czy biernego w nim uczestnictwa. Emocje towarzyszące śledzeniu zmagań ulubionych sportowców powodują szybsze tworzenie skojarzeń i trwalsze zapamiętywanie nazw produktów, firm oraz marek; 
- sport jest dobrym sposobem na promocję ze względu na jego popularność w mediach. Reklama sponsora znajdująca się w miejscu, gdzie odbywa się dane wydarzenie sportowe, widoczna jest $\mathrm{w}$ telewizji, która przeprowadza transmisję lub następnego dnia w prasie. Z kolei umieszczenie firmy sponsorującej w oficjalnej nazwie drużyny, czy imprezy - gwarantuje wymienianie jej nazwy w mediach;

- sport wyzwala wiele skojarzeń, które chcieliby wykorzystać potencjalni sponsorzy, np. precyzja - dla urządzeń pomiarowych, dynamika - dla samochodów, zdrowie - dla żywności itp.;

- sport w porównaniu $\mathrm{z}$ tradycyjnymi środkami reklamy jest stosunkowo tanią i efektywną metodą docierania do odbiorów;

- W sporcie nie występują ograniczenia wiekowe, mogą go uprawiać oraz kibicować ulubionym drużyną wszyscy;

- sport jest jednocześnie masowy i elitarny - wydarzeniami sportowymi interesują się w mniejszym bądź większym stopniu wszystkie grupy społeczne.

Sponsoring tytularny, to najwyższa forma sponsoringu, w którym nazwa sponsora staje się integralną częścią nazwy obiektu, wydarzenia, bądź całych rozgrywek. W komunikacji nie zawsze jednak zachowana jest prawidłowa forma nowej nazwy, co często staje się problematyczne, szczególnie w kontekście budowania długofalowej współpracy stron zaangażowanych w dany projekt.

Jednym z największych atutów sponsoringu jest jego aspekt kreowania pozytywnego wizerunku. Firmom, a także podmiotom, które znajdują sponsora, nadaje się podświadomie większą wartość, stają się w odczuciu bardziej prestiżowe, elitarne. Wartość ta wzrasta, wraz z wysoką pozycją sponsora i sponsorowanego, którą zajmują na własnym rynku. Grupa podmiotów sportowych posiadających własnych partnerów tytularnych, jest mocno zawężona. Tego rodzaju kooperacja, przynosi każdej ze stron konkretne korzyści wizerunkowe. Sponsor jest w jeszcze większym stopniu postrzegany jako godny zaufania partner. Swoim wsparciem potwierdza, że zależy mu na rozwoju projektu, w który jest zaangażowany.

Sponsoring drużyn siatkarskich w Polsce stał się bardzo atrakcyjny dla przedsiębiorstw. Sukcesy Polskich drużyn klubowych oraz reprezentacyjnych przyciągnęły masę fanów. Wartość medialna profesjonalnych lig siatkówki w Polsce wyceniana była na 582 miliony złotych w 2017 roku (Strategia rozwoju Polskiej...). W 2017 roku transmisje klubowych drużyn siatkówki osiągnęły 280 godzin transmisji i przyciągnęły przed telewizory 19500000 widzów. Na halach sportowych w samym 2017 roku zmagania sportowców obejrzało na żywo prawie 700000 widzów (Strategia rozwoju Polskiej...).

Polska wyznacza światowe standardy w zakresie organizacji meczów oraz widowisk siatkarskich. Nasze nowatorskie metody są doceniane przez kibiców siatkówki na całym świecie, jak i przez władze międzynarodowych organizacji siatkarskich. To w Polsce po raz pierwszy rozegrano mecz inauguracyjny 
mistrzostw świata na stadionie piłkarskim, bijąc rekord frekwencji. Niepowtarzalną atmosferę podczas meczów siatkówki w Polsce próbują naśladować kibice innych krajów.

Polska Liga Siatkówki S.A. oraz PlusLiga i Liga Siatkówki Kobiet - ze względu na pozycje liderów na rynku polskiego profesjonalnego sportu, w oparciu o lojalną, wartościową marketingowo widownię, najwyższy zwrot z inwestycji poniesionej w sponsoring oraz unikalne widowiska siatkarskie i wysoki poziom sportowy rozgrywek - należą do najbardziej atrakcyjnych produktów sponsorskich w Polsce. Nic więc dziwnego, że przedsiębiorstwa w Polsce coraz częściej decydują się na sponsoring tytularny drużyn siatkarskich.

\section{PRZEGLĄD LITERATURY}

Większość badań dotyczących wpływu wyników sportowych na notowania spółek opiera się na modelach ekonometrycznych. Do najczęściej wykorzystywanych metod należą:

- regresja liniowa (Bell i in., 2012; Demir i Danis, 2011; Aglietta i in., 2010; Sarac i Zeren, 2013);

- modele ARCH, GARCH, EGARCH (Douque i Ferreira, 2005; Berument i in., 2006; Edmans i in., 2007; Berument i Ceylan, 2012; Majewska i Majewski, 2018; Majewski, 2014; 2015);

- modele strukturalne (Samagaio i in., 2009);

- testy statystyczne (Bell i in., 2012);

- test przyczynowości Grangera (Leitao i in., 2012).

Zwykle w badaniach wpływu zdarzeń sportowych na kursy akcji koncentrowano się na wydarzeniach związanych z piłką nożną, a konkretniej wpływie wyników konkretnych drużyn na kursy akcji sponsorów tytularnych, właścicieli klubów itd. Do badań tego typu można zaliczyć:

- Stadtmann (2004), badał m. in. wpływ wyników Borussi Dortmund,

- Ashton i in. (2003), badali wpływ wyników drużyn z ligi angielskiej,

- Edmans i in. (2007), badali wpływ wyników rozgrywek piłkarskich na poziomie drużyn międzynarodowych,

- Bell i in. (2012), badali wpływ wyników drużyn z ligi angielskiej,

- Sarac i Zeren (2013), badali wpływ trzech klubów z piłkarskiej ligi tureckiej,

- Majewska i Majewski (2018), zbadali wpływ wyników Bayernu Monachium, Borussi Dortmund Liverpoolu i Juventusu Turyn na notowania spółek sponsorujących,

- Majewski (2014), zbadał wpływ wyników drużyn AS Roma, Juventus Turyn i Lazio na kursy na giełdzie tychże spółek. 


\section{METODYKA}

W pracy zbadano wpływ wyników drużyn siatkarskich na dochodowość spółki, rozumianej jako stopa zwrotu z akcji na giełdzie. Idea badań opiera się na założeniu, że istnieje statystycznie istotny związek między stopami zwrotu i wynikami meczów. Zakładamy, że każde oficjalne zwycięstwo w grze i każda przegrana wywiera wpływ na ruch cen akcji - pozytywny dla zwycięstw i negatywny dla strat. Podstawowy model regresji, przedstawiający wpływ sportowych czynników $\mathrm{X}_{\mathrm{kt}}$ na stopy zwrotu spółki $\mathrm{R}_{\mathrm{Xt}}$ przedstawia się następująco:

$$
R_{X t}=\alpha_{0}+\sum_{k=1}^{n} \gamma_{k} X_{k t}+\varepsilon_{t}
$$

Sprawdzenie wpływu wyników na ceny akcji sprowadza się do badania istotności parametru $\gamma_{\mathrm{k}}$ stojącego przy określonej zmiennej. Wynikiem estymacji parametrów modelu jest odpowiedź na pytanie czy czynniki o charakterze sportowym i prognozy bukmacherskie mają istotny wpływ na kształtowanie się kursów spółek giełdowych.

Większość badań wskazuje na związek między stopami zwrotu klubów piłkarskich notowanych na giełdach i ich wynikami sportowymi, a najlepszymi modelami ukazującymi ten związek były modele $\mathrm{z}$ autoregresyjną heteroscedastycznością warunkową (Majewska i Majewski, 2018). Z tego powodu, wpływ wyników w siatkówce na dochodowość akcji spółek został zweryfikowany na podstawie modeli klasy ARCH i GARCH.

Podstawowy model ARCH (Engle, 1982):

$$
h_{t}=\alpha_{0}+\sum_{s=1}^{S} \alpha_{s} \varepsilon_{t-s}^{2}, \text { gdzie } \alpha_{0}>0,0<\alpha_{s}<1, \varepsilon_{t} \sim N\left(0, h_{t}\right)
$$

Podstawowy model GARCH (Bollerslev, 1986):

$$
h_{t}=\alpha_{0}+\sum_{S=1}^{S} \alpha_{s} \varepsilon_{t-s}^{2}+\sum_{q=1}^{Q} \beta_{q} h_{t-q}, \text { gdzie } \alpha_{0}>0, \alpha_{s}, \beta_{q} \geq 0
$$

Równania modeli $\mathrm{ARCH}(1)$ oraz $\operatorname{GARCH}(1,1)$ zostały estymowane metodą największej wiarygodności.

Zmienne wykorzystane w modelu:

$\mathrm{R}_{\mathrm{X}(\mathrm{t})}$ - stopa zwrotu ze spółki w okresie $\mathrm{t}$

$\mathrm{R}_{\mathrm{X}(\mathrm{t}-1)}$ - stopa zwrotu ze spółki w okresie $\mathrm{t}-1$

$\mathrm{R}_{\mathrm{WIG}(\mathrm{t})}$ - stopa zwrotu z WIG w okresie $\mathrm{t}$

W - wygrana, zmienna zero-jedynkowa, przyjmuje wartość 1, gdy zespół wygra mecz 
L - przegrana, zmienna zero-jedynkowa, przyjmuje wartość 1, gdy zespół przegra mecz

$\mathrm{P}_{\mathrm{W}}$ - prawdopodobieństwo wygranej,

$\mathrm{P}_{\mathrm{L}}$ - prawdopodobieństwo przegranej,

$\mathrm{MD}$ - dzień meczu, zmienna zero-jedynkowa,

$\mathrm{P}, \mathrm{W}, \mathrm{S}, \mathrm{C}, \mathrm{Pt}$ - kolejne dni tygodnia, zmienna zero-jedynkowa.

Prawdopodobieństwo wygranej i przegranej zostało obliczone na podstawie kursów bukmacherskich (betting odds) i zawiera się w przedziale 0-100\%. Przy wyjaśnianiu zależności stóp zwrotu od wyników sportowych należy wyeliminować inne potencjalne efekty - na przykład kalendarzowy efekt dnia tygodnia, stąd wykorzystanie zmiennych ,dni tygodnia”.

Dla każdej spółki estymowano modele GARCH i ARCH z następującymi zmiennymi zależnymi:

1. $\mathrm{R}_{\mathrm{WIG}(t)}, \mathrm{W}, \mathrm{L}, \mathrm{P}_{\mathrm{W}}, \mathrm{P}_{\mathrm{L}}$

2. $\mathrm{R}_{\mathrm{X}(\mathrm{t}-1)}, \mathrm{R}_{\mathrm{WIG}(\mathrm{t})}$

3. $\mathrm{MD}, \mathrm{P}, \mathrm{W}, \mathrm{S}, \mathrm{C}, \mathrm{Pt}$

4. $\mathrm{W}, \mathrm{L}$

5. $\mathrm{P}_{\mathrm{W}}, \mathrm{P}_{\mathrm{L}}$

\section{PRÓBA BADAWCZA}

Badaniem zostały objęte cztery drużyny siatkarskie z polskiej ligi i spółki, przedstawione w tabeli 1.

Dane dotyczące meczy wygranych, przegranych oraz kursy bukmacherskie pochodzą ze strony www.betexplorer.com. Notowania spółek zostały pobrane ze strony www.stooq.pl. Estymacje zostały dokonane za pomocą oprogramowania GRETL.

Tabela 1. Drużyny i spółki objęte badaniem

\begin{tabular}{|c|c|c|}
\hline Drużyna & Spółka & Okres objęty badaniem \\
\hline PGE Skra Bełchatów & PGE SA & $09.11 .2009-30.05 .2019$ \\
\hline ZAKSA Kędzierzyn-Koźle & Grupa Azoty SA & $22.09 .2008-30.05 .2019$ \\
\hline KS Jastrzębski Węgiel & JSW SA & $30.09 .2011-30.05 .2019$ \\
\hline Asseco Resovia Rzeszów & Asseco SA & $08.10 .2009-30.05 .2019$ \\
\hline
\end{tabular}

Źródło: opracowanie własne. 


\section{WYNIKI}

Łącznie przeprowadzonych zostało 40 estymacji. Tabela 2 pokazuje podsumowanie wszystkich wyników uzyskanych ze wszystkich oszacowanych modeli, natomiast tabele $2-10$ przedstawiają dokładne wyniki estymacji. Tabele $2-4$ przedstawiają wyniki oszacowań dla spółki Asseco.

Tabela 2. Wyniki estymacji modelu GARCH dla zmiennej RASSECO, 2009-10-08 - 2019-05-31

$(\mathrm{N}=2376)$

\begin{tabular}{lr|r|r|r} 
& Współczynnik & \multicolumn{1}{c|}{ Btąd stand. } & \multicolumn{1}{c}{$z$} & \multicolumn{1}{c}{ wartość $p$} \\
\hline stała & 0,000111332 & 0,000312104 & 0,3567 & \multicolumn{1}{c}{0,7213} \\
\hline RwIG(t) & 0,692516 & 0,0311860 & 22,21 & $<0,0001 * * *$ \\
\hline $\mathrm{W}$ & $-0,0189212$ & 0,00697581 & $-2,712$ & $0,0067 * * *$ \\
\hline $\mathrm{L}$ & $-0,0194253$ & 0,00712638 & $-2,726$ & $0,0064 * * *$ \\
\hline $\mathrm{P}_{\mathrm{W}}$ & 0,0190257 & 0,00664782 & 2,862 & $0,0042 * * *$ \\
\hline $\mathrm{P}_{\mathrm{L}}$ & 0,0149131 & 0,00693173 & 2,151 & $0,0314 * *$ \\
\hline
\end{tabular}

\begin{tabular}{lr|r|r|r}
\hline$\alpha_{0}$ & $3,63129 \mathrm{e}-05$ & $1,20581 \mathrm{e}-05$ & 3,012 & $0,0026 * * *$ \\
\hline$\alpha_{1}$ & 0,108030 & 0,0254824 & 4,239 & $<0,0001 * * *$ \\
\hline$\beta_{1}$ & 0,729929 & 0,0730235 & 9,996 & $<0,0001 * * *$ \\
\hline Średn.aryt.zm.zależnej & 0,000293 & Odch.stand.zm.zależnej & 0,016595 \\
Logarytm wiarygodności & 6669,247 & Kryt. inform. Akaike'a & $-13318,49$ \\
Kryt. bayes. Schwarza & $-13260,76$ & Kryt. Hannana-Quinna & $-13297,48$ \\
\hline
\end{tabular}

Źródło: opracowanie własne.

Jak wynika z estymacji wszystkie zmienne okazały się istotne statystycznie i tylko jedna na poziomie istotności 0,05 , natomiast pozostałe na poziomie istotności 0,01 . Co ciekawe zarówno przegrana jak i wygrana wpływały negatywnie na kurs akcji. Natomiast prawdopodobieństwo wygranej i przegranej wpływało pozytywnie na cenę. Te wyniki potwierdzają również estymacje modelu ARCH.

Na podstawie tabeli 3 można wnioskować, że prawdopodobieństwo w sposób dodatni i istotnie statystycznie wywierało wpływ na kurs akcji spółki Asseco. 
Tabela 3. Wyniki estymacji modelu ARCH dla zmiennej RAsseCO, 2009-10-08 - 2019-05-31 $(\mathrm{N}=2376)$

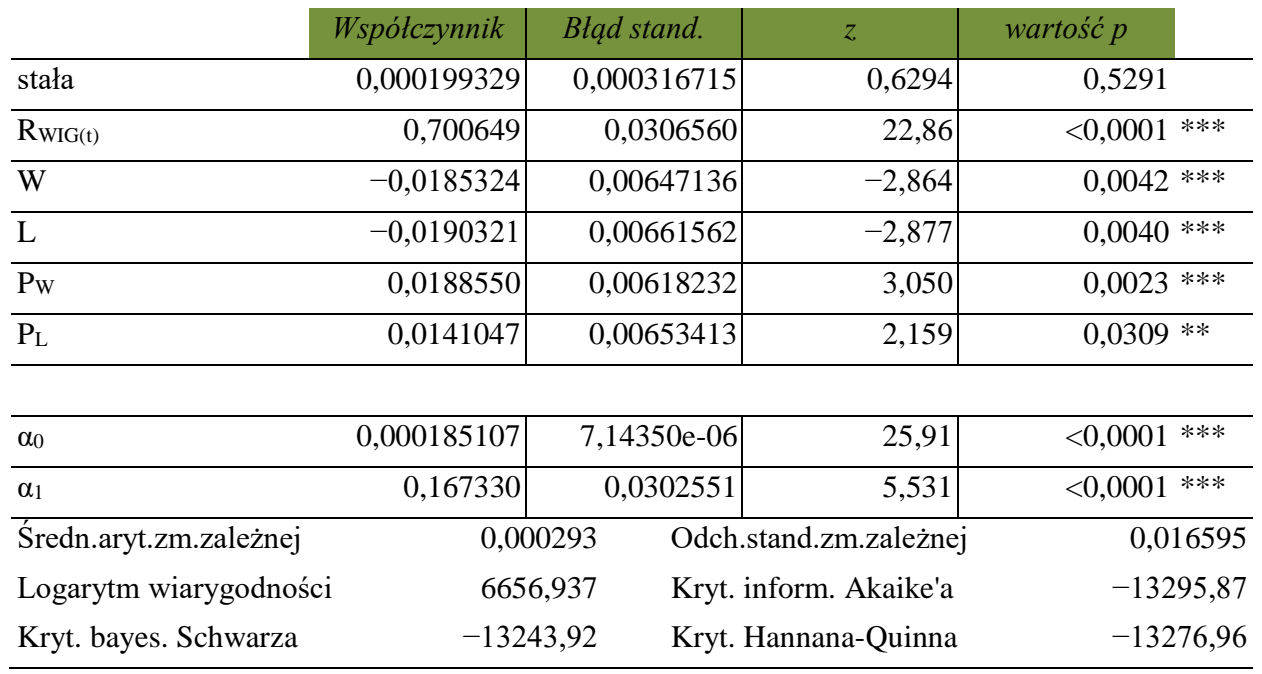

Źródło: opracowanie własne.

Tabela 4. Wyniki estymacji modelu ARCH dla zmiennej RAssECO, 2009-10-08 - 2019-05-31 $(\mathrm{N}=2376)$

\begin{tabular}{lr|r|r|r} 
& Wspótczynnik & Btąd stand. & \multicolumn{1}{c}{$z$} & \multicolumn{1}{c}{ wartość $p$} \\
\hline stała & 0,000355492 & 0,000342269 & 1,039 & 0,2990 \\
\hline $\mathrm{Pw}_{\mathrm{W}}$ & 0,00244872 & 0,00138014 & 1,774 & $0,0760 *$ \\
\hline $\mathrm{PL}_{\mathrm{L}}$ & $-0,00402674$ & 0,00250357 & $-1,608$ & 0,1077 \\
\hline$\alpha_{0}$ & 0,000220978 & $8,55811 \mathrm{e}-06$ & 25,82 & $<0,0001 * * *$ \\
\hline$\alpha_{1}$ & 0,211465 & 0,0324925 & 6,508 & $<0,0001 * * *$ \\
\hline Średn.aryt.zm.zależnej & 0,000311 & Odch.stand.zm.zależnej & 0,016640 \\
Logarytm wiarygodności & 6560,519 & Kryt. inform. Akaike'a & $-13109,04$ \\
Kryt. bayes. Schwarza & $-13074,25$ & Kryt. Hannana-Quinna & $-13096,39$ \\
\hline
\end{tabular}

Źródło: opracowanie własne.

Tabela 5 przedstawia wyniki estymacji dla spółki PGE. W tym przypadku istotna statystycznie na poziomie istotności 0,05 okazała się jedynie zmienna przegrana. Zaskakujące jest to, że przegrana drużyny siatkarskiej miała pozytywny wpływ na notowania spółki. 
Tabela 5. Wyniki estymacji modelu ARCH dla zmiennej RPGE, 2009-10-26 - 2019-05-31

$(\mathrm{N}=2353)$

\begin{tabular}{l|c|c|c|c} 
& Wspótczynnik & Błąd stand. & $z$ & wartość $p$ \\
\hline Stała & $-0,00022449$ & 0,000394445 & $-0,5691$ & 0,5693 \\
\hline $\mathrm{W}$ & $-3,1098 \mathrm{e}-05$ & 0,00119266 & $-0,02608$ & 0,9792 \\
\hline $\mathrm{L}$ & 0,00484233 & 0,00209735 & 2,309 & $0,0210 \quad * *$ \\
\hline
\end{tabular}

\begin{tabular}{l|c|c|c|rr}
\hline$\alpha_{0}$ & 0,000291450 & $1,10221 \mathrm{e}-05$ & 26,44 & $<0,0001$ & $* * *$ \\
\hline$\alpha_{1}$ & 0,140814 & 0,0286580 & 4,914 & $<0,0001$ & $* * *$ \\
\hline Średn.aryt.zm.zależnej & \multicolumn{7}{c|}{$-0,000100$} & Odch.stand.zm.zależnej & 0,018412 \\
Logarytm wiarygodności & 6118,130 & Kryt. inform. Akaike'a & $-12224,26$ \\
Kryt. bayes. Schwarza & $-12189,65$ & Kryt. Hannana-Quinna & $-12211,66$ \\
\hline
\end{tabular}

Źródło: opracowanie własne.

Tabele 6-9 przedstawiają wyniki oszacowań dla spółki JSW.

Tabela 6. Wyniki estymacji modelu GARCH dla zmiennej RJsw, 2011-09-29 - 2019-05-31

$(\mathrm{N}=1894)$

\begin{tabular}{l|c|c|c|c} 
& Wspótczynnik & Błąd stand. & $z$ & wartość $p$ \\
\hline stała & $-0,00073351$ & 0,000531848 & $-1,379$ & 0,1678 \\
\hline $\mathrm{R}_{\mathrm{WIG}(\mathrm{t})}$ & 1,32813 & 0,0527784 & 25,16 & $<0,0001 \quad * * *$ \\
\hline $\mathrm{W}$ & 0,0122322 & 0,0135520 & 0,9026 & 0,3667 \\
\hline $\mathrm{L}$ & 0,0103492 & 0,0138336 & 0,7481 & 0,4544 \\
\hline $\mathrm{P}_{\mathrm{W}}$ & $-0,0104238$ & 0,0127855 & $-0,8153$ & 0,4149 \\
\hline $\mathrm{P}_{\mathrm{L}}$ & $-0,0115779$ & 0,0131405 & $-0,8811$ & 0,3783 \\
\hline
\end{tabular}

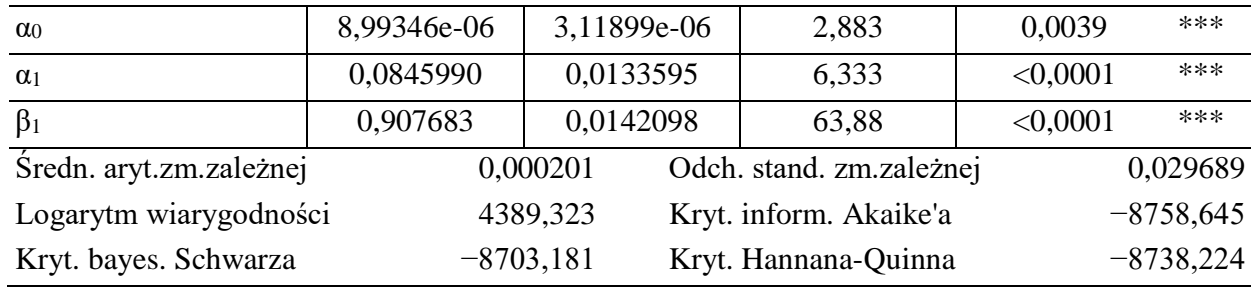

Źródło: opracowanie własne. 
Jak się okazuje, gdy zmienne dotyczące wyniku meczu oraz prawdopodobieństwa są jednocześnie włączone do modelu jedynie zmienna kontrola (stopa zwrotu z WIG) okazuje się istotna statystycznie. Jest to całkiem naturalne, ponieważ sytuacja na rynku z pewnością wpływa na notowania poszczególnych spółek. Jednak gdy zmienne dotyczące wyniku meczu i prawdopodobieństwa zostaną przedstawione $\mathrm{w}$ oddzielnych modelach pojawiają się istotne statystycznie wyniki.

Tabela 7. Wyniki estymacji modelu GARCH dla zmiennej Rssw, 2011-09-29 - 2019-05-31

$$
(\mathrm{N}=1894)
$$

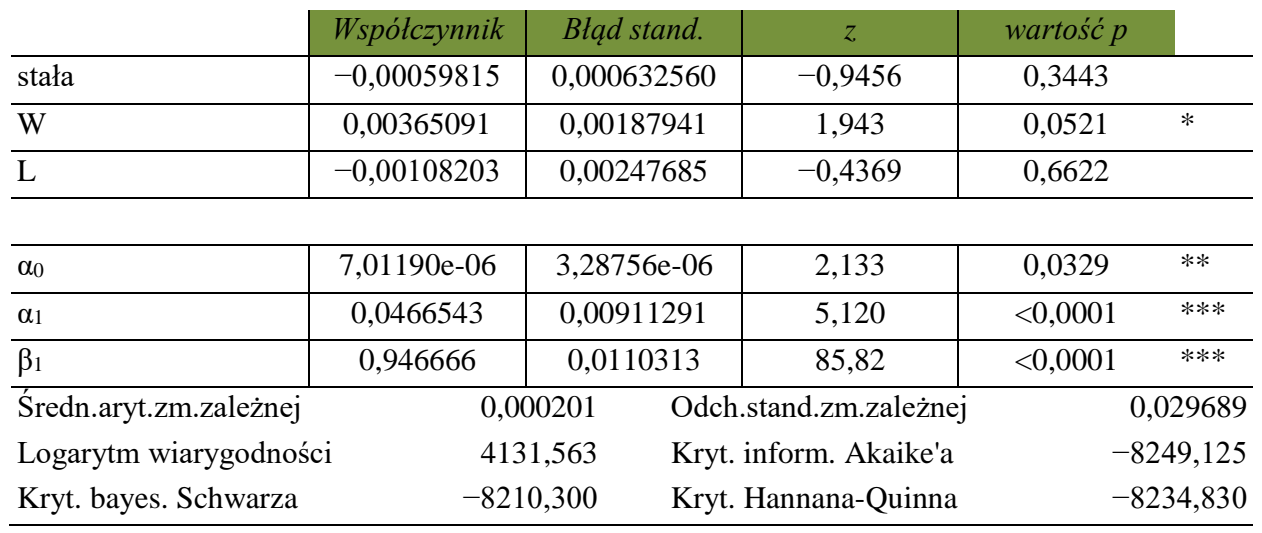

Źródło: opracowanie własne.

Tabela 8. Wyniki estymacji modelu GARCH dla zmiennej RJSW, 2011-09-29-2019-05-31

$$
(\mathrm{N}=1894)
$$

\begin{tabular}{l|c|c|c|cc} 
& Wspótczynnik & Błąd stand. & $z$ & wartość $p$ & \\
\hline stała & $-0,000554487$ & 0,000632454 & $-0,8767$ & 0,3806 & \\
\hline $\mathrm{P}_{\mathrm{W}}$ & 0,00510569 & 0,00265518 & 1,923 & $0,0545 \quad *$ \\
\hline $\mathrm{P}_{\mathrm{L}}$ & $-0,00355957$ & 0,00359312 & $-0,9907$ & 0,3219 & \\
\hline
\end{tabular}

\begin{tabular}{l|c|c|c|cr}
\hline$\alpha_{0}$ & $7,16039 \mathrm{e}-06$ & $3,35737 \mathrm{e}-06$ & 2,133 & 0,0329 & $* *$ \\
\hline$\alpha_{1}$ & 0,0467302 & 0,00913449 & 5,116 & $<0,0001$ & $* * *$ \\
\hline$\beta_{1}$ & 0,946398 & 0,0111497 & 84,88 & $<0,0001$ & $* * *$ \\
\hline $\begin{array}{l}\text { Średn.aryt.zm.zależnej } \\
\text { Logarytm wiarygodności }\end{array}$ & 0,000201 & Odch.stand.zm.zależnej & 0,029689 \\
Kryt. bayes. Schwarza & 4131,351 & Kryt. inform. Akaike'a & $-8248,702$ \\
\hline
\end{tabular}

Źródło: opracowanie własne. 
Zmienne wygrana oraz prawdopodobieństwo wygranej w istotny statystycznie sposób wpływają na notowania spółki. Efekt ten jest dodatni i większy w przypadku prawdopodobieństwa wygranej.

Tabela 9. Wyniki estymacji modelu GARCH dla zmiennej RJsw, 2011-09-29 - 2019-05-31

$(\mathrm{N}=1894)$

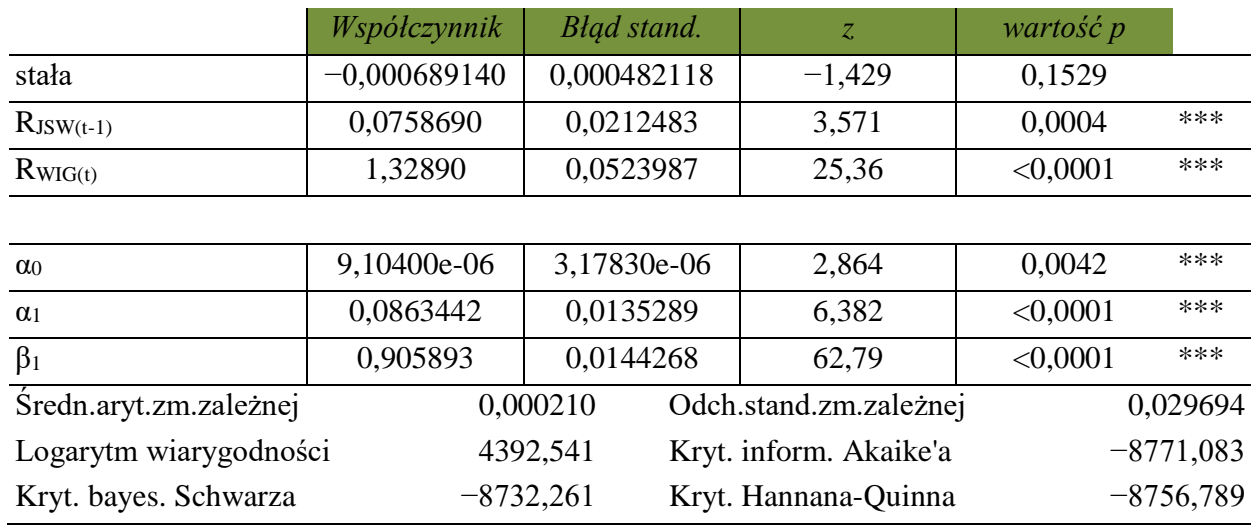

Źródło: opracowanie własne.

Zarówno stopa zwrotu z indeksu głównego jak i stopa zwrotu z dnia poprzedniego w sposób pozytywnie istotny wpływały na kurs akcji JSW. Warto zauważyć, że ani dzień meczu ani żaden z dni tygodnia nie wywierał istotnego wpływu na badaną spółkę.

Na podstawie tabeli 10 należy wnioskować, że wyniki drużyny siatkarskiej nie wpływały na notowania spółki Azoty.

Tabela 11 zawiera zestawienie wyników estymacji dla wszystkich badanych modeli. Można zauważyć, że wyniki drużyn siatkarskich wpływały na dwie z czterech badanych spółek. Rezultat zmagań siatkarskich miał wpływ na kursy spółek JSW oraz ASSECO. Szczególnie silny wpływ wyników sportowych był widoczny w przypadku tej drugiej spółki. Również prawdopodobieństwa wygranej i przegranej wywierały istotny statystycznie wpływ na notowania tych spółek. Natomiast do spółek PGE oraz Azoty wyniki drużyn siatkarskich nie wywierały istotnego statystycznie wpływu na notowania. Na każdą ze spółek wywierał wpływ indeks WIG oraz notowania danej spółki z poprzedniego dnia. Z kolei na żadną ze spółek nie wpływał dzień rozegrania meczu. Nie wykryto także efektów kalendarzowych, które mogłyby wpływać na notowania badanych spółek. 
Tabela 10. Wyniki estymacji modelu GARCH dla zmiennej RAzoty, 2009-10-08 - 2019-05-31

$(\mathrm{N}=2392)$

\begin{tabular}{lc|c|c|c} 
& Wspótczynnik & Błąd stand. & $z$ & wartość $p$ \\
\hline stała & $2,55140 \mathrm{e}-05$ & 0,000475339 & 0,05368 & 0,9572 \\
\hline $\mathrm{R}_{\mathrm{WIG}(\mathrm{t})}$ & 0,904183 & 0,0460234 & 19,65 & $<0,0001$ *** \\
\hline $\mathrm{W}$ & $-0,00050658$ & 0,00941321 & $-0,05382$ & 0,9571 \\
\hline $\mathrm{L}$ & 0,00110351 & 0,00940575 & 0,1173 & 0,9066 \\
\hline $\mathrm{P}_{\mathrm{W}}$ & 0,00178501 & 0,00896853 & 0,1990 & 0,8422 \\
\hline $\mathrm{P}_{\mathrm{L}}$ & $-0,00325776$ & 0,00927908 & $-0,3511$ & 0,7255 \\
\hline
\end{tabular}

\begin{tabular}{|c|c|c|c|c|c|}
\hline$\alpha_{0}$ & 0,000137334 & $2,64612 \mathrm{e}-05$ & 5,190 & $<0,0001$ & $* * *$ \\
\hline$\alpha_{1}$ & 0,162134 & 0,0271755 & 5,966 & $<0,0001$ & *** \\
\hline$\beta_{1}$ & 0,576752 & 0,0669841 & 8,610 & $<0,0001$ & $* * *$ \\
\hline Średn.aryt.zm.zależnej & \multicolumn{2}{|c|}{0,000677} & Odch.stand.zm.zależnej & \multicolumn{2}{|c|}{0,024716} \\
\hline Logarytm wiarygodności & \multicolumn{2}{|c|}{5729,017} & Kryt. inform. Akaike'a & \multicolumn{2}{|c|}{$-11438,03$} \\
\hline Kryt. bayes. Schwarza & \multicolumn{2}{|c|}{$-11380,23$} & Kryt. Hannana-Quinna & \multicolumn{2}{|c|}{$-11417,00$} \\
\hline
\end{tabular}

Źródło: opracowanie własne.

Tabela 11. Syntetyczne zestawienie wszystkich zbadanych modeli

\begin{tabular}{|c|c|c|c|c|c|}
\hline Spółka & Model & Zmienne & $\begin{array}{l}\text { Zmienne istotne } \\
\text { statystycznie }\end{array}$ & Poziom istotności & $\begin{array}{c}\text { Log. } \\
\text { Wiaryg. }\end{array}$ \\
\hline \multirow{10}{*}{$\begin{array}{c}\text { Jastrzębska } \\
\text { Spółka } \\
\text { Węglowa }\end{array}$} & GARCH & $\mathrm{RwIG}_{(\mathrm{t})}, \mathrm{W}, \mathrm{L}, \mathrm{P}_{\mathrm{w}}, \mathrm{P}_{\mathrm{L}}$ & $\operatorname{RWIG}_{(t)}$ & $* * *$ & 4389,323 \\
\hline & GARCH & $\operatorname{RJSW}_{\text {J(t-1), }} \operatorname{RwIG}_{(\mathrm{t})}$ & $\mathrm{RwIG}_{(\mathrm{t})}, \mathrm{RJSW}_{\mathrm{J}}(\mathrm{t}-1)$ & $* * *$ & 4392,541 \\
\hline & GARCH & $\mathrm{MD}, \mathrm{P}, \mathrm{W}, \mathrm{S}, \mathrm{C}, \mathrm{Pt}$ & brak & - & 4130,689 \\
\hline & GARCH & $\mathrm{W}, \mathrm{L}$ & W & $*$ & 4131,563 \\
\hline & GARCH & $\mathrm{P}_{\mathrm{W}}, \mathrm{P}_{\mathrm{L}}$ & $\mathrm{P}_{\mathrm{W}}$ & $* *$ & 4131,351 \\
\hline & $\mathrm{ARCH}$ & $\mathrm{R}_{\mathrm{WIG}(\mathrm{t})}, \mathrm{W}, \mathrm{L}, \mathrm{P}_{\mathrm{W}}, \mathrm{P}_{\mathrm{L}}$ & $\mathrm{R}_{\text {WIG }(t)}$ & $* * *$ & 4250,867 \\
\hline & $\mathrm{ARCH}$ & 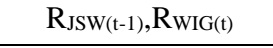 & $\mathrm{R}_{W I G(t)}, \mathrm{R}_{\mathrm{JSW}}(\mathrm{t}-1)$ & $* * *$ & 4264,493 \\
\hline & $\mathrm{ARCH}$ & $\mathrm{MD}, \mathrm{P}, \mathrm{W}, \mathrm{S}, \mathrm{C}, \mathrm{Pt}$ & brak & - & 4037,025 \\
\hline & $\mathrm{ARCH}$ & $\mathrm{W}, \mathrm{L}$ & brak & - & 4037,061 \\
\hline & $\mathrm{ARCH}$ & $\mathrm{P}_{\mathrm{w}}, \mathrm{P}_{\mathrm{L}}$ & $\mathrm{P}_{\mathrm{w}}$ & $*$ & 4036,808 \\
\hline
\end{tabular}




\begin{tabular}{|c|c|c|c|c|c|}
\hline \multirow{10}{*}{$\begin{array}{l}\text { Polska Grupa } \\
\text { Energetyczna }\end{array}$} & GARCH & $\mathrm{R}_{\mathrm{WIG}(\mathrm{t})}, \mathrm{W}, \mathrm{L}, \mathrm{P}_{\mathrm{W}}, \mathrm{P}_{\mathrm{L}}$ & $\mathrm{R}_{\mathrm{WIG}(\mathrm{t})}$ & $* * *$ & 6529,673 \\
\hline & GARCH & $\mathrm{RJSW}_{(\mathrm{t}-1), \operatorname{RwIG}(\mathrm{t})}$ & RwIG(t) & $* * *$ & 6526,856 \\
\hline & GARCH & $\mathrm{MD}, \mathrm{P}, \mathrm{W}, \mathrm{S}, \mathrm{C}, \mathrm{Pt}$ & brak & - & 6164,609 \\
\hline & GARCH & $\mathrm{W}, \mathrm{L}$ & brak & - & 6163,86 \\
\hline & GARCH & $\mathrm{P}_{\mathrm{W}}, \mathrm{P}_{\mathrm{L}}$ & brak & - & 6164,037 \\
\hline & $\mathrm{ARCH}$ & $\mathrm{R}_{\mathrm{WIG}(\mathrm{t})}, \mathrm{W}, \mathrm{L}, \mathrm{P}_{\mathrm{W}}, \mathrm{P}_{\mathrm{L}}$ & $\mathrm{RWIG}_{\mathrm{W}(\mathrm{t})}$ & $* * *$ & 6474,453 \\
\hline & $\mathrm{ARCH}$ & 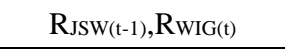 & $\mathrm{R}_{W I G(t)}$ & $* * *$ & 6471,477 \\
\hline & $\mathrm{ARCH}$ & $\mathrm{MD}, \mathrm{P}, \mathrm{W}, \mathrm{S}, \mathrm{C}, \mathrm{Pt}$ & brak & - & 6083,865 \\
\hline & $\mathrm{ARCH}$ & W, L & $\mathrm{L}$ & $* *$ & 6118,130 \\
\hline & $\mathrm{ARCH}$ & $\mathrm{P}_{\mathrm{W}}, \mathrm{P}_{\mathrm{L}}$ & $\mathrm{P}_{\mathrm{L}}$ & $*$ & 6117,505 \\
\hline \multirow{10}{*}{ ASSECO } & GARCH & $\mathrm{RwIG}_{(\mathrm{t})}, \mathrm{W}, \mathrm{L}, \mathrm{P}_{\mathrm{w}}, \mathrm{P}_{\mathrm{L}}$ & $\begin{array}{c}\text { RwG(t), W, L, Pw, } \\
P_{L}\end{array}$ & $* * *$ & 6669,247 \\
\hline & GARCH & 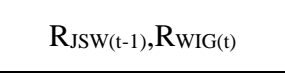 & $\begin{array}{c}\mathrm{R}_{W I G(t)}, \mathrm{R}_{\mathrm{ASSECO}(\mathrm{t}-} \\
1)\end{array}$ & $* * *$ & 6679,613 \\
\hline & GARCH & $\mathrm{MD}, \mathrm{P}, \mathrm{W}, \mathrm{S}, \mathrm{C}, \mathrm{Pt}$ & brak & - & 6587,776 \\
\hline & GARCH & $\mathrm{W}, \mathrm{L}$ & brak & - & 6587,454 \\
\hline & GARCH & $\mathrm{P}_{\mathrm{w}}, \mathrm{P}_{\mathrm{L}}$ & brak & - & 6587,907 \\
\hline & $\mathrm{ARCH}$ & $\mathrm{R}_{\mathrm{WIG}(\mathrm{t})}, \mathrm{W}, \mathrm{L}, \mathrm{P}_{\mathrm{W}}, \mathrm{P}_{\mathrm{L}}$ & $\begin{array}{c}R_{W I G(t)}, W, L, P_{W}, \\
P_{L} \\
\end{array}$ & $* * *$ & 6656,937 \\
\hline & $\mathrm{ARCH}$ & 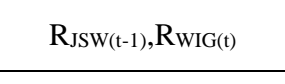 & $\begin{array}{c}\text { RWIG(t), RASSECO(t- } \\
1)\end{array}$ & $* * *$ & 6662,453 \\
\hline & $\mathrm{ARCH}$ & $\mathrm{MD}, \mathrm{P}, \mathrm{W}, \mathrm{S}, \mathrm{C}, \mathrm{Pt}$ & brak & - & 6559,561 \\
\hline & $\mathrm{ARCH}$ & $\mathrm{W}, \mathrm{L}$ & brak & - & 6559,312 \\
\hline & $\mathrm{ARCH}$ & $\mathrm{P}_{\mathrm{w}}, \mathrm{P}_{\mathrm{L}}$ & $\mathrm{P}_{\mathrm{W}}$ & $*$ & 6560,519 \\
\hline \multirow{10}{*}{ Grupa Azoty } & GARCH & $\mathrm{R}_{\mathrm{WIG}(\mathrm{t})}, \mathrm{W}, \mathrm{L}, \mathrm{P}_{\mathrm{W}}, \mathrm{P}_{\mathrm{L}}$ & $\mathrm{R}_{\text {WIG }(t)}$ & $* * *$ & 5729,017 \\
\hline & GARCH & 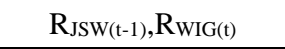 & $R_{W I G(t)}, R_{\text {AZOTY }(t-1)}$ & $* * *$ & 5729,566 \\
\hline & GARCH & $\mathrm{MD}, \mathrm{P}, \mathrm{W}, \mathrm{S}, \mathrm{C}, \mathrm{Pt}$ & brak & - & 5551,219 \\
\hline & GARCH & $\mathrm{W}, \mathrm{L}$ & brak & - & 5550,278 \\
\hline & GARCH & $\mathrm{P}_{\mathrm{W}}, \mathrm{P}_{\mathrm{L}}$ & brak & - & 5550,398 \\
\hline & $\mathrm{ARCH}$ & $\mathrm{R}_{\mathrm{WIG}(\mathrm{t})}, \mathrm{W}, \mathrm{L}, \mathrm{P}_{\mathrm{W}}, \mathrm{P}_{\mathrm{L}}$ & $\mathrm{RWIG}_{(\mathrm{t})}$ & $* * *$ & 5699,204 \\
\hline & $\mathrm{ARCH}$ & 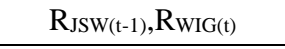 & $R_{W I G(t)}, R_{\text {AZOTY(t-1) }}$ & $* * *$ & 5701,111 \\
\hline & $\mathrm{ARCH}$ & $\mathrm{MD}, \mathrm{P}, \mathrm{W}, \mathrm{S}, \mathrm{C}, \mathrm{Pt}$ & brak & - & 5516,815 \\
\hline & $\mathrm{ARCH}$ & $\mathrm{W}, \mathrm{L}$ & brak & - & 5516,159 \\
\hline & $\mathrm{ARCH}$ & $\mathrm{Pw}_{\mathrm{w}} \mathrm{P}_{\mathrm{L}}$ & brak & - & 5516,036 \\
\hline
\end{tabular}

Źródło: opracowanie własne. 


\section{PODSUMOWANIE}

Dotychczasowe badania wpływu wyników sportowych na kursy akcji na giełdzie skupiały się jedynie na wynikach drużyn piłkarskich. Przykładem badań dotyczących wpływu wyników sportowych drużyny na strategicznego sponsora zajmowali się (Majewska i Majewski, 2018). W artykule zbadano wpływ wyników Bayernu Monachium, Borussi Dortmund Liverpoolu i Juventusu Turyn na notowania spółek sponsorujących. W przypadku Liverpoolu nie ma znaczenia, czy drużyna wygra, czy przegra; każda impreza sportowa, w której bierze udział ta drużyna, ma wpływ na stopy zwrotu sponsora. Z kolei w przypadku BVB każda przegrana ma negatywny wpływ na stopy zwrotu akcji.

Według autorów warte uwagi jest również wpływ wyników meczów w innych dyscyplinach sportu na notowania spółek. W artykule zbadano wpływ wyników drużyn siatkarskich na kursy akcji sponsorujących je spółek. Na podstawie estymacji modeli uzyskano dwie grupy wyników. Dla dwóch spółek - JSW i ASSECO - wyniki sportowe drużyn siatkarskich i prognozy bukmacherskie dotyczące ich meczów miały istotny statystycznie wpływ na notowania tych spółek. Dla spółki JSW wygrana drużyny sponsorowanej wpływa pozytywnie na kurs akcji notowanych na GPW. Dla spółki ASSECO zarówno wygrana jak i przegrana drużyny sponsorowanej ma negatywny wpływ na ceny akcji. Dla dwóch spółek - PGE oraz Azoty - nie wykazano takiego związku. Ponadto na każdą ze spółek istotny statystycznie wpływ wywierał indeks WIG oraz notowania danej spółki z poprzedniego dnia. Z kolei na notowania żadnej ze spółek nie wpływał dzień rozegrania meczu. Nie wykryto także efektów kalendarzowych, które mogłyby wpływać na notowania badanych spółek.

Należy zaznaczyć, że każde studium przypadku powinno być traktowane indywidualnie i nie należy uogólniać, że zawsze spółka-sponsor odczuje wpływ rezultatów na kursy na giełdzie. Czasami ceny akcji reagują na wyniki meczów piłki siatkowej, a czasami ceny akcji nie reagują w ogóle.

\section{BIBLIOGRAFIA}

Aglietta, M., Andreff, W. and Drut, B. (2010). Floating European football clubs in the stock market. EconomiX Working Paper, 2010-24, https://economix.fr/pdf/dt/2010/WP_EcoX_2010-24.pdf [dostęp 30.06.2020].

Ashton, J.K., Gerrard, B. and Hudson, R. (2003). Economic impact of national sporting success: Evidence from the London stock exchange. Applied Economics Letters, 10(12), pp. 783-785.

Bell, A.R., Brooks, C. and Markham, T. (2012). Does Managerial Turnover Affect Football Club Share Prices? Aestimatio, the IEB International Journal of Finance, 7, http://ssrn.com/abstract=2057601 [dostęp 30.06.2020]. 
Bell, A.R., Brooks, C., Matthews, D. and Sutcliffe, C. (2012). Over the moon or sick as a parrot? The effects of football results on a club's share price. Applied Economics, 44(26), pp. 34353452.

Berument, H. and Ceylan, N.B. (2012). Effects of soccer on stock markets: The return-volatility relationship. The Social Science Journal, 49(3), pp. 368-374.

Berument, H., Ceylan, N.B. and Gözpınar, E. (2006). Performance of soccer on the stock market: Evidence from Turkey. The Social Science Journal, 43(4), pp. 695-699.

Bollerslev, T. (1986). Generalized autoregressive conditional heteroscedasticity. Journal of Econometrics, 31, pp. 307-327.

Datko, M. (2003). Sponsoring sportowy. W: Marketing sportowy. Możliwości, szanse, korzyści, zagrożenia. Poznań: Wydawnictwo PRODRUK, pp. 97-99.

Demir, E. and Daniş H. (2011). The Effect of Performance of Soccer Clubs on Their Stock Prices: Evidence from Turkey. Emerging Markets and Trades, 47, pp. 58-70.

Douque, J. and Ferreira, N.A. (2005). Explaining Share Price Performance of Football Clubs Listed on the Euronext Lisbon. ISEG - Universidade Tecnica de Lisboa Business Administration Working Paper, 05-01, https://ssrn.com/abstract=675633 [dostęp 30.06.2020].

Edmans, A., Garcia, D. and Norli, O. (2007). Sports Sentiment and Stock Returns. Journal of Finance, 62(4), pp. 1967-1998.

Engle, R. (1982). Autoregressive conditional heteroskedasticity with estimates of the variance of UK inflation. Econometrica, 50, pp. 987-1007.

Iwan, B. (2010). Nowe trendy w marketingu sportowym. Zeszyty Naukowe SGGW, Polityki Europejskie, Finanse i Marketing, 3(52), pp. 353-367.

Leitão, J., Armada, M.R. and Ferreira, J. (2012). Corruption and Co-Movements in European Listed Sport Companies: Did Calciocaos really matter? Munich Personal RePEc Archive Paper, 42474, pp. 65-96.

Majewska, A. i Majewski, S. (2018). Econometric modelling of market prices of football clubs' sponsors' stocks. Aestimatio, The Ieb International Journal Of Finance, 17, ss. 2-17.

Majewski, S. (2014). Wpływ wyników sportowych MUFC na kursy akcji i kwotowania indeksów na giełdach w Nowym Jorku i Londynie. Annales Universitatis Mariae Curie-Skłodowska, Lublin - Polonia, XLVIII(3), ss. 207-218.

Majewski, S. (2015). Is It a Business Feeding on Emotions or an Act of Altruism? The Case of Financing Football in Poland. Acta Universitatis Lodziensis Folia Oeconomica, 1(310), pp. 71-85.

Samagaio, A., Couto, E. and Caiado, J. (2009). Sporting, financial and stock market performance in English football: an empirical analysis of structural relationships. Centre for Applied Mathematics and Economics (CEMAPRE) Working Papers, 0906, https://cemapre.iseg.ulisboa.pt/archive/preprints/395.pdf [dostęp 30.06.2020].

Saraç, M. and Zeren, F. (2013). The Effect of Soccer Performance on Stock Return: Empirical Evidence From "The Big Three Clubs" of Turkish Soccer League. Journal of Applied Finance \& Banking, 3(5), pp. 299-314.

Stadtmann, G. (2004). An Empirical Examination of the News Model: The Case of Borussia Dortmund GmbH \& Co. KGaA. Zeitschrift für Betriebswirtschaft, 74(2), pp. 165-185.

Strategia rozwoju Polskiej ligi siatkówki S.A. na lata 2018 - 2022 - Raport stworzony przez Polską Ligę Siatkówki S.A., http://dl.siatkarskaliga.pl/298780/attachment/746d81/Strategia_37.pdf [dostęp 30.06.2020].

Strony internetowe:

Asseco Resovia, www.assecoresovia.pl [dostęp 23.11.2019].

BetExplorer, www.betexplorer.com [dostęp 23.11.2019].

JSW, www.jastrzebskiwegiel.pl [dostęp 23.11.2019].

PlusLiga, www.plusliga.pl [dostęp 23.11.2019]. 
Skra, www.skra.pl [dostęp 23.11.2019].

Stooq, www.stooq.pl [dostęp 23.11.2019].

Zaksa, www.zaksa.pl [dostęp 23.11.2019].

\section{WYNIKI SPORTOWE A DOCHODOWOŚĆ AKCJI SPÓŁEK-SPONSORÓW NA PRZYKŁADZIE PIŁKI SIATKOWEJ}

\section{Streszczenie}

Przedmiot badań: Przedmiotem badań jest wpływ wyników sportowych, a konkretnie wyników drużyn siatkarskich mężczyzn, na dochodowość akcji (stopy zwrotu) spółek sponsorujących drużyny. Do tej pory badania dotyczące wpływu wyników sportowych na stopy zwrotu koncentrowały się jedynie na piłce nożnej.

Cel badawczy: Celem pacy jest zbadanie zależności między wynikami sportowymi drużyn siatkarskich w Polsce a stopami zwrotu sponsora tytularnego, którego akcje notowane są na Giełdzie Papierów Wartościowych w Warszawie. Do badania wybrano 4 najbardziej utytułowane drużyny siatkarskiej PlusLigi w XXI wieku.

Metodyka: W artykule opisano rezultaty badań uzyskane dzięki zastosowaniu modeli klasy ARCH i GARCH.

Wyniki: Na podstawie estymacji modeli uzyskano dwie grupy wyników. Dla dwóch spółek - JSW i ASSECO - wyniki sportowe drużyn siatkarskich i prognozy bukmacherskie dotyczące ich meczów miały istotny statystycznie wpływ na notowania tych spółek. Dla dwóch spółek - PGE oraz Azoty nie wykazano takiego związku. Ponadto na każdą ze spółek istotny statystycznie wpływ wywierał indeks WIG oraz notowania danej spółki z poprzedniego dnia. Z kolei na notowania żadnej ze spółek nie wpływał dzień rozegrania meczu.

Słowa kluczowe: ekonomia sportu, giełda, modele ARCH I GARCH, wyniki sportowe, siatkówka. 